IRA-International Journal of Management \&

Social Sciences

ISSN 2455-2267; Vol.15, Issue 02 (May, 2019)

Pg. no. 44-47.

Institute of Research Advances

http://research-advances.org/index.php/RAJMSS

\title{
Social Traditions and the Violation of Women's Right in the Tagin Society of Arunachal Pradesh
}

\section{Dr Bijay Raji}

Principal (I/C), Govt. College, Daporijo, P.O. Daporijo-791 122, Dist. Upper Subansiri, Arunachal Pradesh, India.

Type of Work: Peer Reviewed.

DOl: http://dx.doi.org/10.21013/jmss.v15.n2.p4

Raji, B. (2019). Social Traditions and the Violation of Women's Right in the Tagin Society of Arunachal Pradesh. IRA-International Journal of Management \& Social Sciences (ISSN 24552267), 15(2), 44-47. doi:http://dx.doi.org/10.21013/jmss.v15.n2.p4

\section{(C) Institute of Research Advances.}

\section{(cc) EY-NC}

This work is licensed under a Creative Commons Attribution-Non Commercial 4.0 International License subject to a proper citation to the publication source of the work.

Disclaimer: The scholarly papers as reviewed and published by the Institute of Research Advances (IRA) are the views and opinions of their respective authors and are not the views or opinions of the IRA. The IRA disclaims of any harm or loss caused due to the published content to any party.

Institute of Research Advances is an institutional publisher member of Publishers International Linking Association Inc. (PILA-CrossRef), USA. The institute is an institutional signatory to the Budapest Open Access Initiative, Hungary advocating the open access of scientific and scholarly knowledge. The Institute is a registered content provider under Open Access Initiative Protocol for Metadata Harvesting (OAI-PMH).

The journal is indexed \& included in WorldCat Discovery Service (USA), CrossRef Metadata Search (USA), WorldCat (USA), OCLC (USA), Open J-Gate (India), EZB (Germany) Scilit (Switzerland), Airiti (China), Bielefeld Academic Search Engine (BASE) of Bielefeld University, Germany, PKP Index of Simon Fraser University, Canada. 
There are 26 major tribes and 110 sub tribes in Arunachal Pradesh. Out of these tribes and sub tribes, Tagin is one of the major tribes in Arunachal Pradesh. The Tagin are descendants of Abo Tani They are settled in Upper Subansiri District of Arunachal Pradesh, bordering east with Galo, west south with Nyishi and North with the Tibet (China). The Tagins are recognized as a separate tribal group very lately ${ }^{1}$. Macknise had noted thatDafla living on the border of North Lakhimpur was known as Tagin Dafla. " "Till very recently the Bagins, a Western branch of the Dafla tribe, occupying wild terrain in the east of Kameng and west of the Subansiri call the Daflas across the frontier of the Kameng district Tagins. Here, the term Tagin implies the sense of being an eastern people".

It is stated in the Assam Census report of 1881 that Daflas called the Miri 'Bodo' and Abor 'Tagin' but observed at the same time that this last word Taginis seemed to be merely the name of a tribe common to theAbor (Adi) and Dafla (Nyishing).

After Achinmori massacre of 1953, Tagins are recognized as a separate tribe having an affinity with both Adi in the east and Nyishing in the south west ${ }^{4}$. Agriculture is the mainstay of the Tagins. Apart from agriculture, they engage in hunting, rearing of Mithun (Bosfrontails) and petty trades. Tagins used to keep slaves and hostage too in their society. Inter-tribe marriages are rare but inter-clan marriages are very common.

The main element of society is the clan organization. The Tagin society consists of a number of clans like Tamin, Tasi, Topo, Hachi, Tani, Tator, Leye, TachiTagia, Bagang, etc ${ }^{4}$. The Taginsociety is patrilineal, patriarchal, patrilocal and endogamous. The woman of Tagin tribe is part of one billion rising campaign states, once in three women on the planet will be raped or beaten in her lifetime.

According to UN observation, 50\% of women who die from homicides worldwide are killed by their current/former husbands/partner. Women perform $66 \%$ of the world work, produce $50 \%$ of the food, but earn only $10 \%$ of income. According to the World Bank, eliminating all forms of discrimination against women is up to $40 \%{ }^{5}$. Feminizing state $40 \%$ of the child soldiers of the world are girls. The 26 million people are forced to flee their homes every year due to armed conflict ${ }^{6}$.

In North East India, armed violence has taken its toll on the very notion of "normal civilian life" and led to innumerable instances of violations committed against civilian populations particularly women by both state and non-state actors. In most operations, be they cordon and search, combing, arrests, searches, or interrogation, the armed forces have, under the Aegis of Armed Forces Special Power Act 1958 (AFSPA) done away with the basic, minimal safeguard accorded to women suspects by the criminal procedure code as well as the SC directives. Arrest by male security personnel, interrogation in army camps and police stations, torture and sexual abuse including raped by security personnel in custody has become routine.

In short, women are facing violence and discrimination both in conflict as well as nonconflict areas and the numbers is increasing ${ }^{7}$.

As another part of the globe, there are many forms of gender discrimination and violation of women Right in Tagin society. Here the scholar picked up the subtopic, "the social tradition and violation of women Right".

As per Tagin social tradition, the status of the Tagin women is less than that of man. After marriage, some bride price is paid to the parent of the bride. The marriage system of Tagin gives some solid evidence of gender discrimination and violation of women right. In the Tagin society, there are the provision of womb marriage, child marriage, forced marriage and widow marriage etc. Before the birth of a female child, the parent arranges her marriage. After child marriage and womb marriage when bride and bridegroom grow up, sometimes the girls are forced to marry her partner though she may not love and ready to marry her partner. Once the girl is engaged for marriages, she is bound to marry her partner. Even if she is not ready to marry and denies to marriage, she is bound to go for under trial such as Lepia (Leg cup) ${ }^{8}$. She will be kept in Lepia till she gets pregnant. She will be rapidly raped by her husband. The widow remarriage is permitted to only her deceased husband's brother and a cousin or parallel clan brother. The widow cannot remarriage any stranger other than her deceased husband clan. These forceful marriages lead to gender discrimination and violation of women right. Out of frustration, sometimes girl and women commit suicide. Polygamy is another factor which leads to gender discrimination and violation of women rights. The man can marry as many as women as he likes to do so. If women divorce her husband, the parents of women refund all bride price to the bridegroom's party. 
Traditionally women of Tagin Society cannot member of the village council (Dopam). The women only give evidence and lodge complains in the Dopam. They render their service in serving food and drinks during the session of Village Council. ${ }^{9}$ This shows that there are political discrimination and violation of women right in the Tagin society.

Though, the Tagin societies are not divided into any caste and sect. Socially there is a lot of restriction and taboo for women in society. During their menstruation period, they are to stay away from the house until the completion of their menstruation. They are not allowed to perform any ritual and attend auspicious occasion during menstruation period. The women and girl are not allowed to sit like a man. They are bending to kneel down before menfolk. There is a specific place for women in the house. The women and her girl child are to sleep and stay at the corner of the house near the hearth (Nyodii) ${ }^{10}$. The women and girl are not allowed to giggle in front of male members and elder persons.

Food and drink are essential for every living thing. Even than gender discrimination and violations of women right are also seen in Food habit of Tagin society. There are many restrictions and taboo for Tagin girls and women in food and drink. The young girls are taboo to eat mutton, pork (especially abdomens part of the pig), monkey meat etc. They are restricted to take the meat of wild animal (especially upper portion including head) ${ }^{1}$. During pregnancy period the women are restricted to take some wild animal meat and pork, beef, mutton chicken etc. and to engage in some specific ritual (Puja). Though there are many restrictions and taboo for women men are free to eat everything in the society

Domestic violence is frequently seen in Tagin society. The women have treated inferiority in society. The rate of compensation against the crime to a woman is less than a man. For example, murder for a man may go up to 20 to 50 Mithun and fine or compensation for women range only up to 10 to 20 Mithun ${ }^{12}$. As per Tagin customary law, there is no capital punishment for rape and murder in society. The heinous crime against women can easily be compensated by fine.

As per Article 39 of the Indian Constitution, there should be equal pay for equal work. But Tagin society has a different norm. The women are paid less than men for equal work. For instance, the wage of per day agriculture work, men are paid Rs. 250 and women are paid Rs.200.

Property is important assets that determine the status of man in society. Certain property is owned by an individual as well as a clan in Tagin society. The inheritance of property in society is regulated according to the customary law of the society. Its violation viewed seriously and the lawbreakers are severely punished in society.

Being matrilineal, patriarchal and patrilocal society, all immovable property is inherited by the male heir. The girl child can only inherit movable properties such as live stocks, utensils, ornaments, clothes, agriculture implements, etc. Even the widow has no right to inherit the immovable property of her deceased husband. If the widow got a male heir, she has the right to look after her deceased husband immoveable property till her heir grow up and capable to take care of his deceased father's property. If she has no male heir, all her deceased husband's immovable property will be inherited by her brother-in-law. She has no right to sell her deceased husband's immovable property. These shows even in the economic sphere, there are gender discrimination and violation of women right in Tagin society.

Gender is still playing the most important factor in determining leadership. Traditionally, leadership had been monopolized by the men. Before the advancement of modern administration, the Tagin did not recognize the women leadership in society. Due to the influence of modern administration and outsider, few women are appointed as village GaonBurhi, political Interpreters (Kotoki) and Panchayat leaders. Gender discrimination in leadership is declining in the society especially after passing of Arunachal Pradesh Panchayat, Act 1997. A good number of women leadership appeared in society after this act. At present, there are 168 Gram Panchayat members, 35 AnchalSamity members and 3 Zila Parishad members.

Gender discrimination and violation of women right is one of the biggest challenges before Tagin society in particular and Arunachal Pradesh in general. Here the scholar suggests few points overcome gender discrimination 
and violation of women right in general and Tagin society in particular. Education is one of the best instruments to overcome gender discrimination and violation of women right. Through education, the mindset of people can change. They can understand the right of women and their feeling and importance in society. An educated woman can fight for their equal right and social causes.

Educated women can understand their right, value and rationalize social causes of society. Once they rationalize their right and value in society, the polygamy, child marriage, forced marriage will be stopped in the society. When child marriage and forced marriage will be stopped, the exchange of bride price will be declined. Once the society imbibes scientific temper and spirit, the social taboo against the women will disappear.

There should be NGOs and well organize association in society. These NGOs and association should advocate for the upliftment of women in the society. They should fight on behalf of women whenever any gender discrimination and violation of women right is seen. They should initiate to file a case and take appropriate action against the culprits. Apart from NGO's the government should take up some preventive measure for the upliftment of women in the Tagin society in particular and Arunachal in general. The government should establish women cell in every office and institution.

The government should pave an opportunity to girl child for education, vocational training, technical knowledge, entrepreneurship, etc. The vocational training, technical knowledge and entrepreneurship would help the unemployed women to get a job in government or private sector and they would also get self-employment. These opportunities help women to make a self-dependent and sound economy. The educated and self-dependent women can liberate from the social traditional web of society. When they are out of social and tradition webs, gender discrimination and violation of women right will be declined.

\section{References}

[1]. Dubey, Sanjay (1996): Dynamics of Tribal Local Polity and Panchayat Raj in Arunachal Pradesh, Premiere Publishing House, New Delhi, p.11

[2]. Choudhury J. N. (1986): Arunachal Panorama, Directorate of Research, Government of Arunachal Pradesh, Itanagar. P. 134

[3]. Ibid:p 134

[4]. Ibid:p.135

[5]. The Arunachal Times, Friday, $8^{\text {th }}$ March 2013

[6]. ibid:

[7]. ibid:

[8]. An interview with YekarTadik at Leje Rijo,9th January 2012.

[9]. Ibid.

[10]. An interview with HaliTapak at Dumporijo, 20 January 2012

[11]. Ibid.

[12]. Ibid. 